\title{
DIREITO À CIDADE E EXPANSÃO URBANA: INTERFERÊNCIA DO PLANO DIRETOR NA ATUAÇÃO DOS AGENTES PRODUTORES DO ESPAÇO EM ARACAJU-SE, BRASIL
}

Sarah Lucia Alves França ${ }^{1}$

\section{RESUMO}

Semelhante à maioria das cidades brasileiras, a expansão urbana de Aracaju-SE obedeceu à lógica dos agentes imobiliários e do Estado, privilegiando interesses econômicos e caracterizando-se como um campo de lutas e disputas sócioespaciais. A legislação através da obrigatoriedade do Plano Diretor em 2000, aponta diretrizes pautadas no controle do uso e ocupação do solo, liberando e restringindo a escolha das áreas apropriadas pelo mercado para construção de condomínios fechados, ou pelo Estado para implantação de conjuntos habitacionais e de infraestrutura. Assim, este artigo busca analisar o papel do Plano Diretor de Desenvolvimento Urbano - PDDU da capital sergipana, como impulsionador da atuação da Prefeitura e do capital imobiliário no processo de expansão e, este se constitui num instrumento de efetivação do direito à cidade. Observa-se, nos últimos anos, que o PDDU, através do macrozoneamento e seus índices, tem permitido a ocupação para áreas com precária infraestrutura e acessibilidade, presença de grandes vazios e elementos ambientais. De fato, o crescimento fragmentado é fruto de uma legislação ineficaz, que reforça a segregação e exclusão social. Para o desenvolvimento deste, foram realizados levantamentos documentais referentes à legislação e aos empreendimentos, quantificando-os e mapeando-os a fim de subsidiar a análise desse referido processo.

Palavras-chave: Direito à Cidade; Plano Diretor; Expansão urbana; Estado; Mercado Imobiliário.

\footnotetext{
${ }^{1}$ Doutora em Arquitetura e Urbanismo pela Universidade Federal Fluminense - PPGAU/UFF Professora Adjunta do Departamento de Arquitetura e Urbanismo - DAU da Universidade Federal de Sergipe - CampusLar. Líder do Centro de Estudos, Planejamento e Práticas Urbanas e Regionais - CEPUR. Graduada em Arquitetura e Urbanismo pela Universidade Tiradentes (2004) e especialista em Planejamento Urbano e Gestão das Cidades pela Universidade Salvador-UNIFACS, Mestre e Doutora em Arquitetura e Urbanismo pela Universidade Federal Fluminense/RJ. Professora adjunta do Departamento de Arquitetura e Urbanismo da Universidade Federal de Sergipe e Líder do Centro de Estudos de Planejamento e Práticas Urbanas e Regionais - CEPUR. Avaliadora da Revista Direito à Cidade, Becária Tesista do Lincoln Institute of Land Policy, Membro da Rede Latino Americana de Investigadores sobre Teoria Urbana, e integrante de grupos de pesquisa em cidades, planejamento urbano e ambiental e direito urbanístico. Conselheira Estadual do CAU-SE e membro das Comissões de Ética, Ensino e Formação, e Política Urbana e Ambiental. Tem experiência em Projetos de Arquitetura e Urbanismo, Planejamento Urbano e Regional, em ênfase em Planos Diretores, Planos de Habitação, Planos de Governo e Diagnósticos Urbanos e Ambientais. E-mail: sarahfranca@ig.com.br
} 


\section{ABSTRACT}

Similar to most Brazilian cities, the urban expansion of Aracaju-SE obeyed the logic of real estate agents and the State, privileging economic interests and characterizing itself as a field of struggles and sociospatial disputes. The legislation, mandated by the Directing Plan in 2000, sets forth guidelines for the control of land use and occupation, freeing and restricting the choice of areas appropriate for the construction of closed condominiums, or by the State for the implementation of housing and infrastructure projects. Thus, this article seeks to analyze the role of the Urban Development Master Plan - PDDU of the Sergipe capital, as a driver of the actions of the City Hall and real estate capital in the process of expansion, and this constitutes an instrument for the realization of the right to the city. In recent years, it has been observed that the PDDU, through macro-zoning and its indexes, has allowed the occupation of areas with poor infrastructure and accessibility, presence of large voids and environmental elements. In fact, fragmented growth is the result of ineffective legislation that reinforces social segregation and exclusion. For the development of this, documentary surveys were carried out regarding legislation and undertakings, quantifying and mapping them in order to support the analysis of this process.

Palavras-chave: Justice to the City; Master plan; Urban expansion; State; Real estate market.

\section{INTRODUÇÃO}

Capitais como Aracaju e outras cidades de porte médio têm vivenciado a expansão urbana no Brasil. O urbano se fragmenta em diversas direções, intercalando ocupação e vazios, guardados pela especulação imobiliária, formando espaços cada vez mais polinucleados e segregados, além de criar novas dinâmicas espaciais, novos modos de vida e alterar paisagens.

Essa produção urbana, protagonizada pelo capital, é resultado de processos privados e/ou públicos provenientes da atuação dos agentes modeladores do espaço e suas formas variadas de apropriação da terra. Neste sentido, é importante observar a terra como mercadoria, variando o seu valor de acordo com a sua localização, presença de elementos ambientais, intervenções públicas e privadas, e ainda a legislação urbana.

Um dos mais importantes agentes na produção de cidade e que deveria proporcionar a todos os cidadãos a efetivação do direito à cidade assegurado pela Constituição Federal e Estatuto da Cidade, é o Estado, que tem cooperado para hierarquização do espaço e escassez de terras urbanizadas, aprofundando as desigualdades sociais. Por sua vez, o setor imobiliário apropria-se da capacidade de estruturar o espaço conforme seus interesses capitalistas, atendendo a uma lógica de produção e de 
transformação dos usos do solo. Uma das suas táticas é buscar junto aos governos locais condições para a viabilização de seus produtos, através do suporte de infraestrutura e da permissividade da legislação, sobretudo Plano Diretor e códigos de obras e urbanismo.

Aracaju, situada no Nordeste do Brasil, abriga 641.523 habitantes (estimativa IBGE, 2016), em uma área de $182 \mathrm{~km}^{2}$ que ocupa 0,79\% do território sergipano. A capital do Estado de Sergipe apresentou um dinamismo na produção do espaço urbano para reprodução do capital, sobretudo de forma mais intensa, a partir dos anos 2000 (após promulgação do Plano Diretor), mediante apoio do Estado, através de legislações urbanísticas, financiamentos em intervenções urbanas e incentivo ao crédito imobiliário pelo Governo Federal.

Nesse período, a crescente ampliação no número de licenciamentos de empreendimentos imobiliários, ativada pelo aquecimento da construção civil no país, sobretudo com o incentivo ao crédito imobiliário, contribuiu na busca por novas áreas de consumo de terras. Além disso, o fortalecimento de grandes construtoras favoreceu a atuação deste agente, resultando o adensamento de bairros urbanizados, ou criação de áreas novas em bairros distantes do centro, gerando novas configurações sócioespaciais.

Diante do exposto, esta pesquisa tem como objetivo analisar o papel do Plano Diretor de Desenvolvimento Urbano - PDDU de Aracaju-SE, como impulsionador da atuação da Prefeitura e do capital imobiliário no processo de expansão e, este se constitui num instrumento de efetivação do direito à cidade. Além disso, verifica como a ação pactuada destes agentes privilegia e/ou induz a inserção dos empreendimentos habitacionais construídos em determinadas áreas, criando uma cidade desigual, com segregação de ricos e de pobres, além da oferta de infraestrutura diferenciada.

Para o desenvolvimento deste estudo, oriundo de uma pesquisa de doutoramento, foi realizado um levantamento bibliográfico sobre a temática abordada, ampla coleta de dados nos órgãos públicos, referentes aos empreendimentos imobiliários licenciados e as intervenções do Estado, especialmente legislação e implantação de equipamentos públicos e sistema viário. Esses dados foram organizados sob a forma de tabelas, que quantificaram o volume e características da ocupação, além da produção de cartografia, que permitiu espacializar a dinâmica do adensamento e expansão urbana em Aracaju.

\section{ESTADO E MERCADO IMOBILIÁRIO: PRODUÇÃO CAPITALISTA DO ESPAÇO URBANO DE ARACAJU}

Desde 2000, Aracaju experimentou um crescimento que tem configurado a implosão-explosão urbana, resultando numa forte segregação sócioespacial e fragmentação espacial. Isso significou para os mais pobres, dificuldade de acesso aos serviços de infraestrutura, como transporte, saneamento e drenagem, além dos equipamentos de saúde, educação e lazer. Somado a isso, menores oportunidades de emprego e renda e aumento da violência acarretaram sérios entraves no acesso à uma cidade justa 
e igualitária, acentuando a formação de uma periferia sem qualidade de vida, produzida pelo mercado informal de moradia.

Por outro lado, a autossegregação se fortaleceu, especialmente em espaços cada vez mais fechados e dotados de segurança, como os condomínios residenciais e shoppings centers, se distanciando cada vez mais do caos, da violência e da pobreza. Essa situação marcou uma cidade heterogênea, com formas habitacionais diversas em função dos níveis de renda, acarretando uma ocupação diferenciada do espaço. Essas contradições que permeiam a cidade é o que Lefebvre (2001) denomina como "negatividades do urbano".

Essas divergências socioeconômicas são muito grandes e isso é refletido no espaço e na estruturação urbana da capital. Assim, constatou-se uma variedade de empreendimentos imobiliários, entremeados nos grandes vazios, causando "descontinuidade, fragmentação, [e que] oneram a instalação e manutenção da infraestrutura e serviços urbanos, além de poder intensificar segregações sócio-espaciais" (ARAUJO, 2011, p.171).

Segundo o cadastro imobiliário da Prefeitura Municipal, em 2003 Aracaju contava com 119.999 lotes cadastrados (incluindo vazios), com ligeira redução deste número no ano de 2014 (119.743 lotes). O uso residencial se sobressaiu em maior proporção, com um aumento de quase 7.000 lotes em 11 anos, correspondendo, em 2014, a 70,74\% do total dos lotes existentes (Figura 1 e Tabela 1). A predominância desse uso tem destaque nos bairros São Conrado $(90,50 \%)$ na zona oeste, Bugio $(90,43 \%)$ e Palestina $(89,49 \%)$, localizados na zona norte.

Concomitantemente, o número de vazios também reduziu na mesma proporção, demonstrando que "Aracaju adensou e expandiu progressivamente, transformando os vazios em edificações com determinados usos, o que por um lado é positivo, no tocante ao cumprimento da função social da propriedade" (SEPLOG \& FRANÇA, 2014, p.148). 


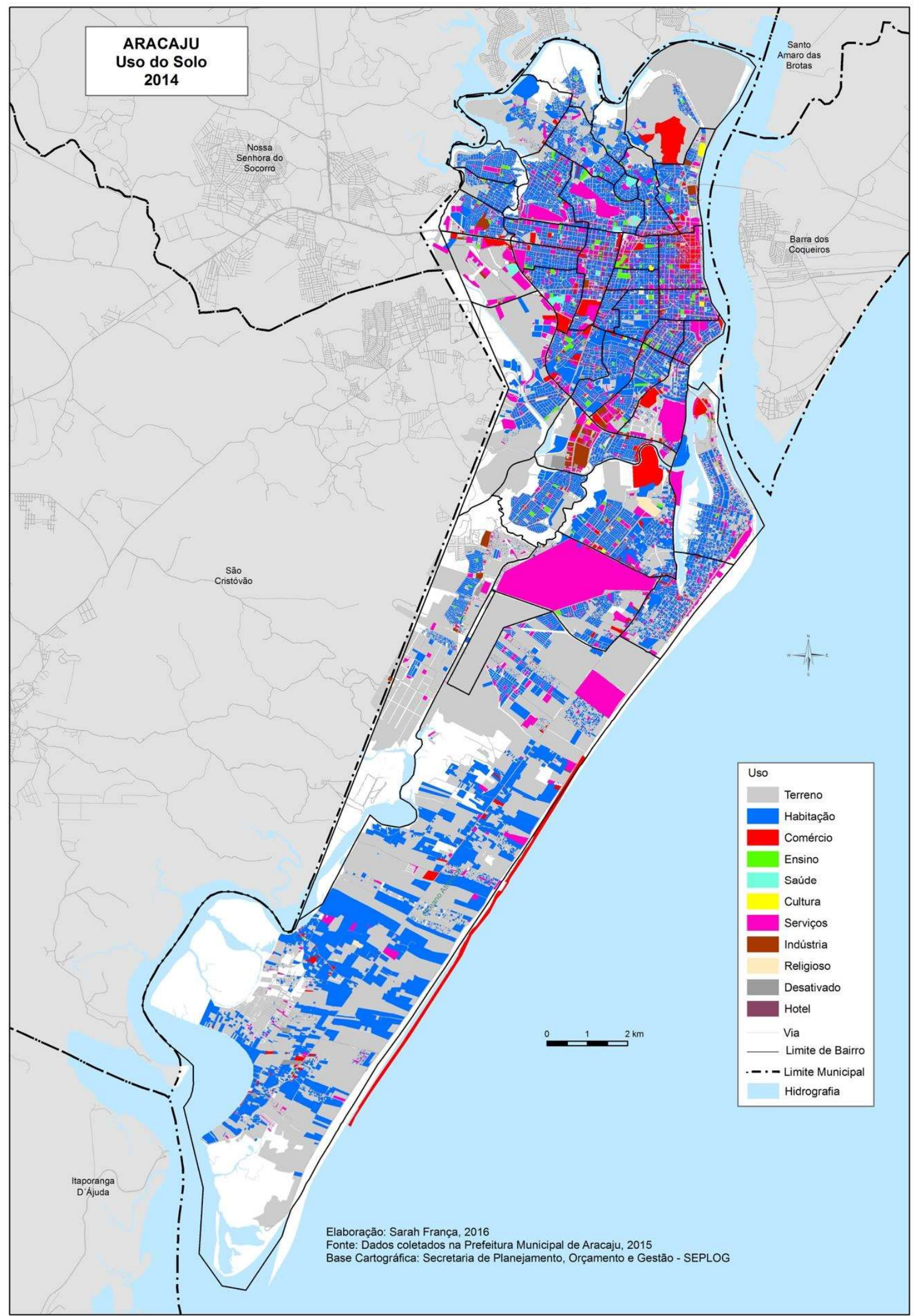

Figura 1: Aracaju, Uso do Solo Predominante por Lote, 2014.

Fonte: FRANÇA, 2016 
Tabela 1

Aracaju

Uso Residencial e Vazios Urbanos

$2003-2010-2014^{2}$

\begin{tabular}{|c|c|c|c|c|c|c|}
\hline & \multicolumn{2}{|c|}{2003} & \multicolumn{2}{c|}{2010} & \multicolumn{2}{c|}{2014} \\
\hline Uso & № de lotes & $\%$ & № de lotes & $\%$ & № de lotes & $\%$ \\
\hline Residencial & 77.540 & 64,56 & 82.375 & 68,65 & 84.714 & 70,74 \\
\hline Vazios Urbanos & 29.998 & 24,98 & 23.329 & 19,44 & 21.860 & 18,25 \\
\hline Total Aracaju & 119.999 & 100,00 & 119.999 & $\begin{array}{c}100,0 \\
0\end{array}$ & 119.746 & $\begin{array}{c}100,0 \\
0\end{array}$ \\
\hline
\end{tabular}

Fonte: SEPLOG \& FRANÇA, 2014.

Nas zonas norte e oeste, os lotes vazios estão reunidos em maior volume nos bairros Porto D'antas $(44,20 \%)$ e Soledade $(39,08 \%)$, enquanto na zona leste destaca-se o Jardins, com $32,60 \%$ do total. Na zona sul, vários bairros ainda concentram grande número de vazios, seguido da Zona de Expansão Urbana e do Santa Maria, onde, respectivamente, 53,49\% e 38,73\% permanecem sem ocupação.

Selecionando aqueles lotes vazios (terrenos) acima de mil metros quadrados, que possibilitam a implantação de empreendimentos residenciais ${ }^{3}$, a grande maioria $(93,71 \%)$, é de propriedade particular, localizados, sobretudo, na parte sul, nos bairros Farolândia, Inácio Barbosa e Zona de Expansão Urbana; ao oeste, nos bairros Jabotiana, Capucho; e na porção norte, nos bairros D'Antas, Lamarão e Soledade. O estoque de terra (vazia) de propriedade da Prefeitura Municipal e do Governo do Estado é reduzido (somam quase 6\%), o que dificulta a realização de projetos sociais, como a construção de equipamentos coletivos, praças e conjuntos habitacionais (Figura 2 e Tabela 2).

O monopólio da propriedade de terra particular é de predomínio das grandes construtoras, sobretudo em bairros como Jardins e 13 de Julho, Luzia, ao norte da ZEU (na antiga Fazenda Nova),

\footnotetext{
${ }^{2}$ As transformações ocorridas na dinâmica urbana e na distribuição espacial do uso do solo, dos últimos anos (2000 a 2012), foram analisadas a partir de dados coletados no Cadastro Multifinalitário, atualizados pela Secretaria Municipal de Fazenda, que em parceria com o setor de Geoprocessamento da Secretaria Municipal de Planejamento, Orçamento e Gestão - SEPLOG mantém essas informações espacializadas, através do Sistema de Informações Geográficas - SIG.

3 Esses lotes vazios (terrenos em construção), maiores são aqueles utilizados para a construção de empreendimentos imobiliários, contribuindo para o adensamento e a expansão urbana, razão porque mereceram destaque.
} 
possibilitando que o capital imobiliário disponibilizasse seus estoques segundo suas necessidades de valorização. Esse fato contribuiu para selecionar as camadas de renda, segundo as exigências da expansão urbana que mais Ihes interessa.

Tabela 2 


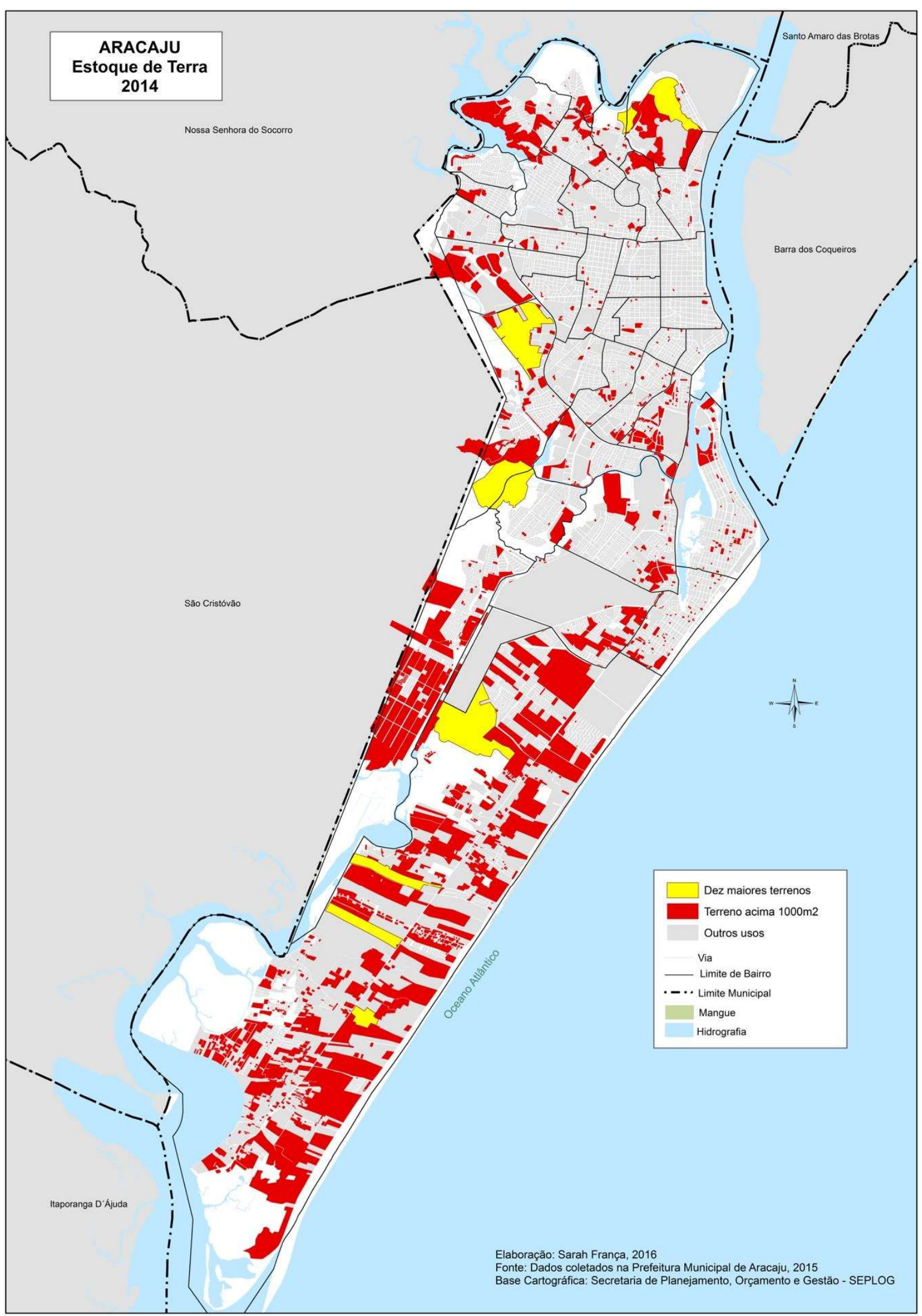

Figura 2: Aracaju, Estoque de lotes vazios maiores que 1.000m², 2014.

Fonte: FRANÇA, 2016 
Tabela 2

Aracaju

Distribuição do Estoque de Terras Urbanas

2014

\begin{tabular}{|c|c|c|c|}
\hline Proprietário & Área $\left(\mathrm{m}^{2}\right)$ & $\begin{array}{c}\mathrm{N}^{\circ} \text { de lotes vazios } \\
\text { com área superior a } \\
1.000 \mathrm{~m}^{2}\end{array}$ & $\%$ \\
\hline Particular & $39.123 .632,62$ & 2.117 & 93,71 \\
\hline Municipal & $2.427 .149,98$ & 67 & 2,97 \\
\hline Estadual & $3.402 .644,14$ & 64 & 2,83 \\
\hline Federal & $110.112,16$ & 6 & 0,27 \\
\hline Religioso & $22.310,51$ & 5 & 0,22 \\
\hline Total & $45.085 .849,41$ & 2.259 & 100,00 \\
\hline
\end{tabular}

Fonte: Dados coletados no cadastro imobiliário, SEPLOG/SEFAZ, 2014.

A partir da análise do estoque de terras e da propriedade particular, entende-se a relevância da interferência do mercado da construção civil no crescimento urbano, direcionando o adensamento e/ou expansão urbana para determinados bairros sem infraestrutura e sem condições de mobilidade, necessitando de controle na ocupação pelo Poder Público, através da legislação municipal (SEPLOG \& FRANÇA, 2014)

A apropriação diferenciada de áreas através da inserção das três tipologias imobiliárias (condomínios horizontais e verticais, loteamentos fechados) e dos conjuntos habitacionais ocorreu atendendo externalidades, como estoque da terra, valor fundiário e o fator localização com as condições ambientais, regulação urbanística e infraestrutura.

Em Aracaju, operam vários agentes imobiliários responsáveis pela produção, ocupação e comercialização do espaço urbano, alterando as formas de uso do solo em detrimento dos seus próprios interesses, associados à valorização da terra. Além disso, Estado acumula funções, quando provém moradia social, constrói avenidas, reformula eixos viários e regulamenta o espaço urbano através da legislação que restringe ou permite a ocupação em zonas. Essas intervenções públicas também contribuíram na expansão e adensamento de bairros e na formação de novos vetores de crescimento urbano. 
Após a promulgação do Plano Diretor, em 2000, até 2014, verificou-se o licenciamento de 519 empreendimentos fechados, sendo mais de $80 \%$ de responsabilidade do mercado imobiliário, resultando em uma oferta de mais de 62 mil unidades habitacionais (FRANÇA, 2016). A apropriação intensiva do espaço dá-se em função da produção habitacional ter se voltado predominantemente para a construção de prédios, em decorrência da escassez de terras e do direcionamento do empreendimento para grupos de renda que priorizam viver em áreas mais adensadas, mais centrais. Sendo assim, observa-se que a construção de condomínios verticais corresponde a $64 \%$ do total de empreendimentos licenciados (Tabela 3).

Tabela 3

Aracaju

Empreendimentos e Unidades Habitacionais por Agente e Tipologia

$2000-2014$

\begin{tabular}{|c|c|c|c|c|}
\hline & Empreendimentos & $\%$ & $\begin{array}{c}\text { Unidades } \\
\text { Habitacionais }\end{array}$ & $\%$ \\
\hline \multicolumn{5}{|c|}{ Estado } \\
\hline Projetos Habitacionais & 06 & 1,15 & 6.704 & 10,70 \\
\hline PAR & 39 & 7,51 & 6.850 & 10,95 \\
\hline PMCMV & 49 & 9,44 & 9.986 & 15,95 \\
\hline Total & 94 & 18,11 & 23.540 & 37,60 \\
\hline Mercado Imobiliário & 334 & 64,35 & 33.832 & 54,06 \\
\hline Condomínio Vertical & 65 & 12,52 & 2.783 & 4,44 \\
\hline Condomínio Horizontal & 26 & 5,00 & 2.432 & 3,88 \\
\hline Loteamento Fechado & 425 & 81,87 & 39.047 & 62,39 \\
\hline Total & 519 & 100 & 62.587 & 100 \\
\hline Total Geral & 34 & & \\
\hline
\end{tabular}

Elaboração Sarah França, 2016.

Fonte: Dados coletados em pesquisa de campo e na Coordenadoria de Urbanismo da Empresa Municipal de Obras e Urbanização - EMURB/PMA, 2015; Prefeitura Municipal e Governo do Estado; Dados fornecidos pela CAIXA (2009; 2015).

É nítida a segregação espacial dos empreendimentos construídos pelo mercado imobiliário e pelo Estado. A seleção das áreas pela iniciativa privada tem relação com a concentração prévia de 
população de maior renda e maior disponibilidade de infraestrutura, comércio e serviços, como ocorre nas zonas leste e sul, até o bairro Aeroporto. No caso dos bairros situados ao longo da faixa litorânea e às margens dos Rios Sergipe e Poxim (como 13 de Julho, Jardins, Coroa do Meio e Atalaia), o mercado se apropriou dessas áreas, em função da exploração do potencial paisagístico, trazendo empreendimentos imobiliários destinados aos moradores de renda mais alta (Figura 3). 


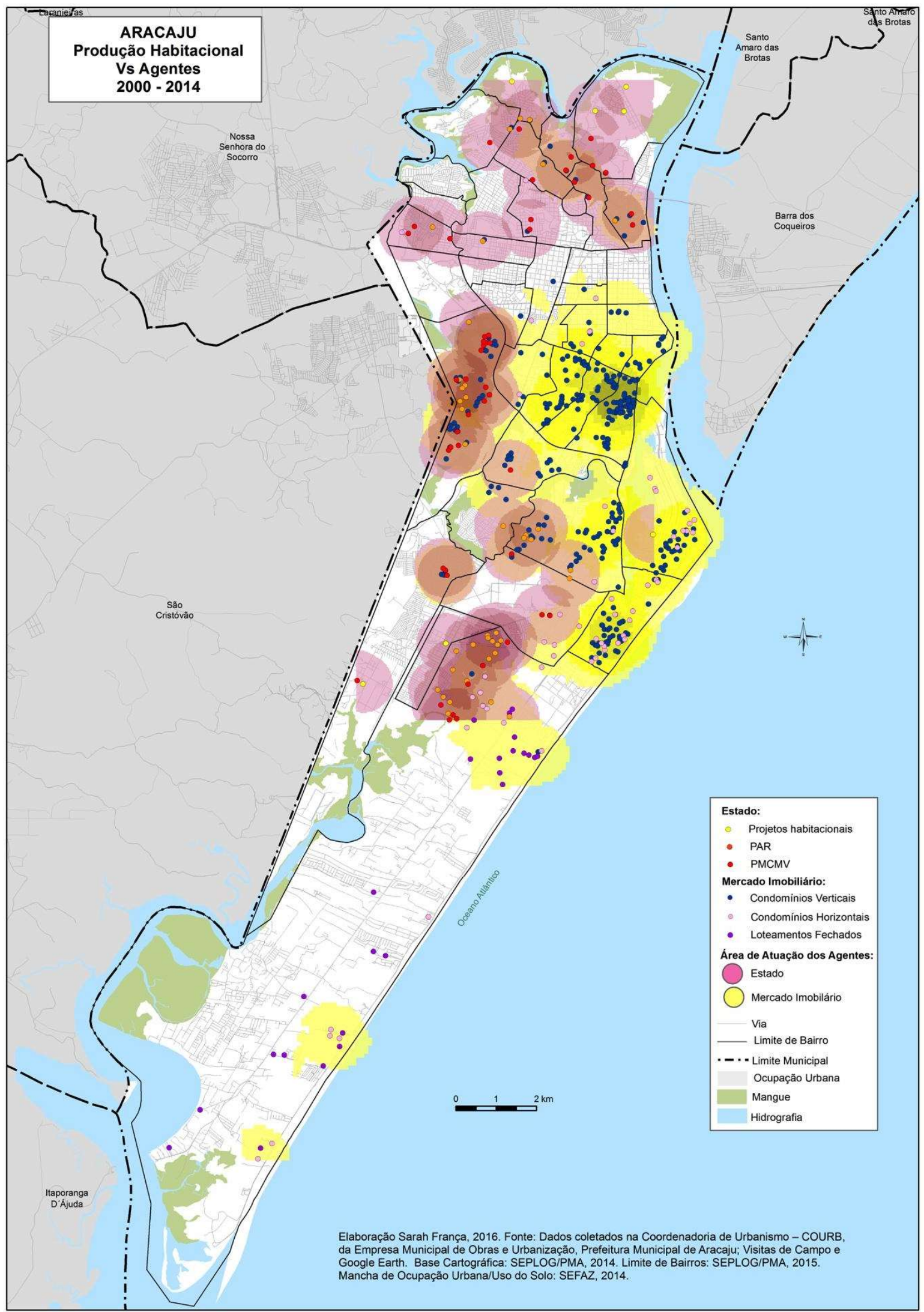

Figura 3: Aracaju, Produção Habitacional X Agentes, 2000-2014.

Fonte: FRANÇA, 2016 
A construção de torres fechadas intramuros nessas áreas valorizadas permitiu enormes ganhos ao setor imobiliário, por possibilitar maior lucratividade em função do maior número de unidades habitacionais em um único terreno. Essa fragmentação fundiária, proporcionada a partir da instituição de uma nova forma de apropriação da terra, que é o condomínio, tornou-se elemento fundamental no avanço das relações capitalistas de produção do espaço.

O setor imobiliário pouco se interessou pelos bairros da zona norte, assinalados pela ocupação popular, com assentamentos precários e irregulares. Isso reduziu os interesses de investimentos, embora haja participação do setor privado na produção habitacional subsidiada pelos Programa de Arrendamento Residencial e o Programa Minha Casa Minha Vida.

Por sua vez, a atuação do Estado ocorreu na periferia dos bairros apropriados pelo mercado, concentrando-se na porção norte, acima das avenidas Coelho Campos e São Paulo, como divisor desta zona. Além dessa, duas outras áreas apresentaram empreendimentos habitacionais construídos com a participação da Prefeitura, com recursos federais, por construtoras locais, a exemplo do Jabotiana, situado ao oeste, e, ao sul, na porção norte da Zona de Expansão Urbana, os empreendimentos do PAR e do PMCMV estão entremeados pelos condomínios horizontais e loteamentos fechados (Figura 3).

Por apresentar um vínculo intrínseco com a apropriação da terra, a habitação tem o espaço como condição fundamental para reprodução do capital, determinando transformações nas relações sócioespaciais. Por isso, a atuação concentrada do capital nos espaços vazios gerou uma maior valorização dos imóveis devido à escassez do solo, que foi estimulada por aqueles que detém o monopólio da distribuição do espaço para as moradias.

Construtoras de médio e grande porte demandam, em sua maioria, por espaços urbanizados, com vizinhança para consumo e investimentos, com interesse em obter rendimentos também advindos da valorização fundiária, ainda que mantenham vazios, em meio ao parcelamento do solo, com abertura de novas vias e logradouros públicos.

Essas empresas se associaram às de porte nacional e regional, como a parceria entre Norcon e Rossi, ou entre firmas locais e regionais, como FelizCidade e Celi. Esse entrelaçamento trouxe uma ampliação na gama de oferta de produtos imobiliários para diferentes classes sociais, em diferentes bairros. Aquelas de pequeno porte direcionam seus produtos a um público de nível de renda menor, sendo os empreendimentos construídos em áreas periféricas ao norte e oeste, com baixo valor fundiário, sem oferta de infraestrutura e acessibilidade, a fim de obter o lucro após a instalação dos primeiros empreendimentos.

Para realizar a comercialização dos seus produtos, as construtoras procuram estimular o comprador, e para tal, limitam-se a garantir condições de acessibilidade, sendo a infraestrutura de 
responsabilidade do poder público. Esse agente procura maximizar seus lucros pela apropriação dos benefícios incorporados pelo Estado e, para isso, utiliza-se de estratégias que consistem em implantar empreendimentos fechados, em bairros distantes das áreas centrais, para obtenção de lucro pelo parcelamento atrelado às futuras intervenções públicas, provenientes de cobranças e pressões desses novos moradores.

Os empreendimentos imobiliários destinados às classes de renda mais elevada e de tipologia verticalizada se concentram na porção leste da cidade, sobretudo entre os bairros 13 de Julho, Atalaia, ao sul e atingindo o Jabotiana, ao oeste. Nas áreas mais próximas ao Centro, e especialmente ao bairro 13 de Julho e Jardins, os imóveis têm valor elevado, resultando numa ocupação vertical que multiplica a quantidade de solo. Esses condomínios fechados estão próximos uns aos outros, e à medida que vão se afastando desses bairros, vão apresentando dimensões menores das unidades habitacionais, consequentemente, destinando-se aos grupos de renda média, especialmente aqueles promovidos pelos Programas de Arrendamento Residencial e o recente Minha Casa Minha Vida.

Ainda em relação à verticalização, o resultado evidente é a apropriação de áreas bastante heterogêneas, como 13 de Julho/Jardins/Grageru, Luzia/Ponto Novo/Suiça e Jabotiana. Dos 175 empreendimentos construídos na zona leste-oeste para faixas de renda diferenciadas, 65 foram localizados nos bairros Luzia, Ponto Novo, Jabotiana apontando a direção de novos vetores de adensamento e de expansão urbana. Além das diferentes características da localização, a diversidade de incorporadores resultou em variações nas tipologias, na qualidade dos materiais, no tamanho e nos atributos internos: área útil, área dos cômodos, número de quartos e de banheiros.

Alguns desses bairros, como o Jabotiana, Luzia e Ponto Novo foram marcados pela modificação da paisagem horizontal imperada pelas residências unifamiliares, que foram, ao longo desses 15 anos, trocadas pelos conjuntos de torres de edifícios implantados em locais como a Alameda das Árvores, no Luzia ou no Ponto Novo, na Avenida Rio de Janeiro.

Outra opção refere-se aos condomínios horizontais e loteamentos fechados, em sua maioria direcionados para população de renda mais elevada, caracterizados pela segregação e homogeneização de níveis econômicos, além de se constituírem, em mansões para veraneio e finais de semana, sobretudo aquelas localizadas no extremo sul. Sua implantação demanda glebas ou lotes com maior área e localização privilegiada com a presença de amenidades naturais. Esse precedente reduz sua oferta em áreas mais centrais, distanciando-os para fora da malha urbana consolidada, e criando assim, novos vetores de expansão urbana, como a Zona de Expansão Urbana.

Examinando a produção habitacional por bairros, foi possível dividir em três períodos. Alguns bairros tiveram uma progressão acentuada na quantidade de empreendimentos licenciados, como o 
Jabotiana, Atalaia, Coroa do Meio, Luzia e Farolândia. O primeiro apresentou, entre 2000 a 2004, apenas 1 condomínio vertical, e nos demais períodos, 14 e 12 respectivamente (Gráfico 1).

Gráfico 1: Aracaju, Produção Habitacional, Periodização por bairros. 2000-2014.

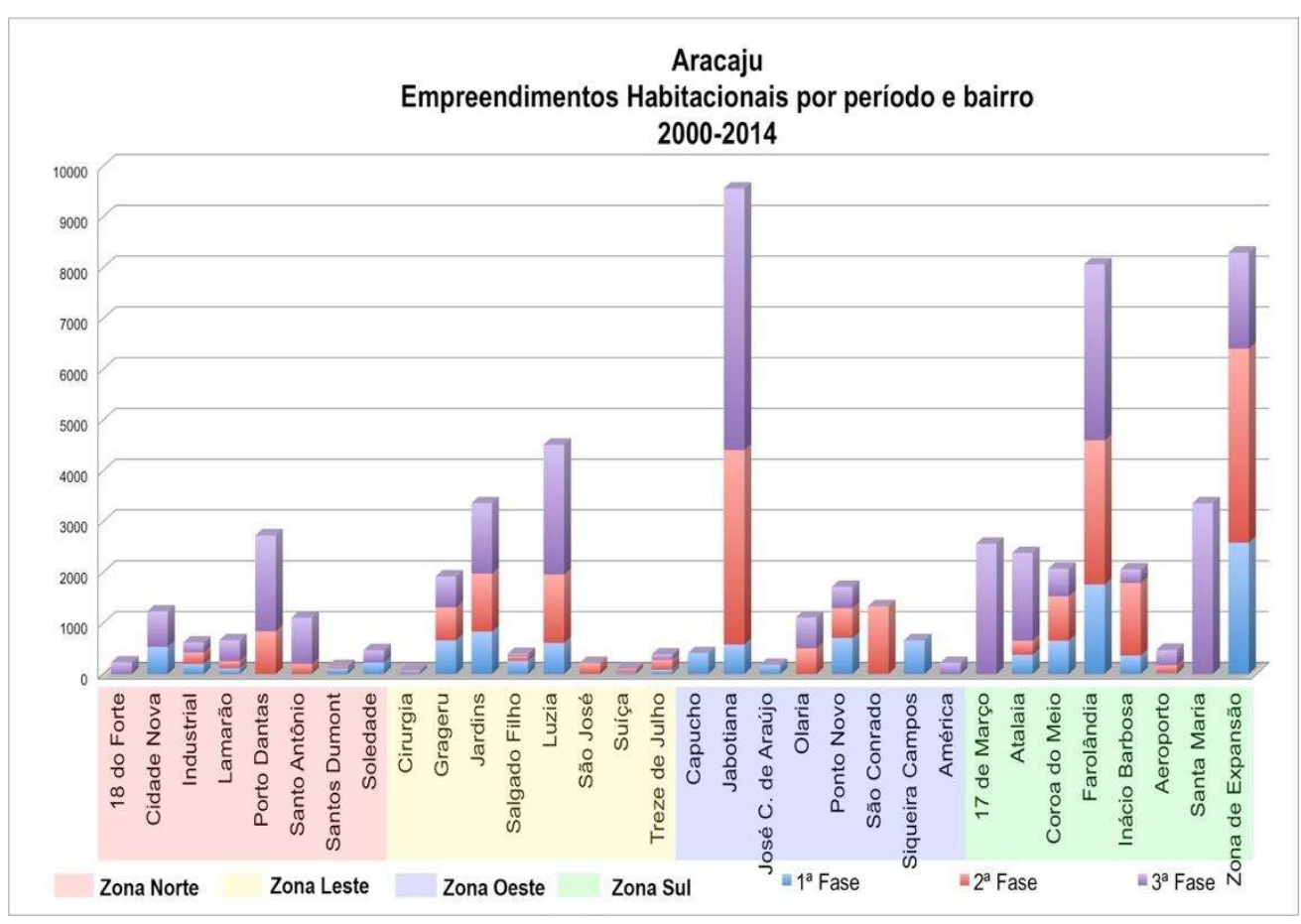

Elaboração Sarah França, 2016.

Fonte: Dados coletados em pesquisa de campo e na Coordenadoria de Urbanismo da Empresa Municipal de Obras e Urbanização - EMURB/PMA, 2015; Prefeitura Municipal e Governo do Estado; Dados fornecidos pela CAIXA (2009; 2015).

Outro exemplo de ascensão foi o bairro Atalaia que, no último período, teve a quantidade de empreendimentos licenciados correspondendo ao dobro dos anteriores. No bairro Coroa do Meio, apesar de serem fechados de pequeno porte (a maioria condomínios horizontais tipo "duplex"), a quantidade destes foi fortemente notada, sobretudo a partir do segundo período. O bairro Luzia, inicialmente, com 5 condomínios verticais, atingiu o número de 15, nos últimos anos, enquanto no bairro Farolândia, o número duplicou a cada ciclo. Os bairros que tiveram a maior produção habitacional foram: Grageru, Jardins, Luzia, Jabotiana, Ponto Novo, Atalaia, Farolândia, Inácio Barbosa, ZEU.

\section{LEGISLAÇÃO URBANA COMO PONTO-CHAVE NA PRODUÇÃO ESPACIAL DA CAPITAL SERGIPANA}

Alguns aspectos influenciaram no adensamento e expansão urbana em Aracaju, como o estabelecimento de normas de controle de uso e ocupação do solo, permitindo e restringindo formas de apropriação de determinadas áreas, a realização de obras e intervenções urbanísticas, especialmente 
no tocante ao sistema viário e implantação de equipamentos coletivos e, por fim, o valor da terra. Esses elementos se constituíram importantes para a escolha das áreas utilizadas pelo mercado imobiliário, para construção de condomínios, ou pelo Estado para implantação de conjuntos habitacionais.

Enfatiza-se a influência da legislação, especialmente das leis complementares inconsistentes e retalhadas, que contrariaram determinações do PDDU, estabelecendo diretrizes que direcionaram as formas de ocupação ou parâmetros urbanísticos que priorizaram determinados grupos econômicos. Uma dessas foi a sucessão de leis que determinaram gabaritos de altura para edificações multifamiliares, as Leis Complementares $n^{\circ}$ 62/2003, no 74/2008 e $n^{0}$ 132/2014, cujas distorções tiveram início ainda nos anos 1970, com a Lei n 466, Resolução n 38/1977 e Decreto n 154/1999, criando uma colcha de retalhos na legislação urbanística de Aracaju e dificultando seu cumprimento.

Quando se sobrepõe o zoneamento apresentado pelo Plano Diretor à produção habitacional, observa-se que embora as diretrizes e índices urbanísticos sirvam para direcionar ou controlar a ocupação, o alto coeficiente de aproveitamento básico de três, determinado para toda cidade, não propiciou a aplicação da Outorga Onerosa do Direito de Construir. Isso resultou na não diferenciação da permissividade da legislação, estimulando a ocupação, em detrimento a outros fatores, em bairros de interesse dos compradores dos produtos imobiliários, como aqueles localizados na Zona de Adensamento Básico - ZAB 2. É aí que se concentram 365 empreendimentos, correspondendo à cerca de 70\% do total produzido entre 2000 a 2014 (Tabela 4 e Figura 4).

Tabela 4

Aracaju

Empreendimentos e Unidades Habitacionais por Zonas de Adensamento $2000-2014$

\begin{tabular}{|c|c|c|c|c|c|}
\hline \multicolumn{2}{|c|}{} & $\begin{array}{c}\text { Área } \\
\left(\mathrm{km}^{2}\right)\end{array}$ & $\%$ & Empreendimentos & $\%$ \\
\hline \multirow{3}{*}{ ZAB } & ZAB 1 & 21,81 & 13,34 & 37 & 7,13 \\
\cline { 2 - 6 } & ZAB 2 & 53,06 & 32,46 & 365 & $\begin{array}{c}70,3 \\
2\end{array}$ \\
\hline \multicolumn{2}{|c|}{ ZAP } & 8,89 & 5,46 & 50 & 9,63 \\
\hline \multicolumn{2}{|c|}{ ZAR } & 79,67 & 48,74 & 67 & 12,9 \\
& & 163,45 & 100 & 519 & 100 \\
\hline
\end{tabular}

Elaboração Sarah França, 2016. 
Fonte: Dados coletados em pesquisa de campo e na Coordenadoria de Urbanismo da Empresa Municipal de Obras e Urbanização - EMURB/PMA, 2015; Prefeitura Municipal e Governo do Estado; Dados fornecidos pela CAIXA (2009; 2015).

A diferenciação que deveria haver entre ZAB 1 e ZAB 2, na prática, não funcionou. Apesar de apresentar cenários divergentes, nessas zonas o coeficiente de aproveitamento máximo varia entre 3,00 e 4,00, sendo que a Outorga Onerosa do Direito de Construir é isenta para toda a cidade, até esse último índice. Outros fatores foram responsáveis pela não apropriação da terra na zona norte pelo mercado imobiliário, como os níveis de renda da população e a oferta de infraestrutura disponível, com poucas melhorias nesses anos.

A Zona de Adensamento Básico 1 contempla bairros localizados na zona norte, como Porto D’Antas, Lamarão, Industrial, cujas famílias pertencem a classe de renda média e baixa. A maioria dos 37 empreendimentos são fruto de programas habitacionais, como o PAR e o PMCMV, ou projetos realizados pela Prefeitura, contrapondo-se às tipologias implantadas na ZAB 2, de condomínios verticais direcionados às classes de renda média e alta, construídos, em sua grande maioria, pelo mercado imobiliário, o maior agente interessado e atuante neste espaço. 


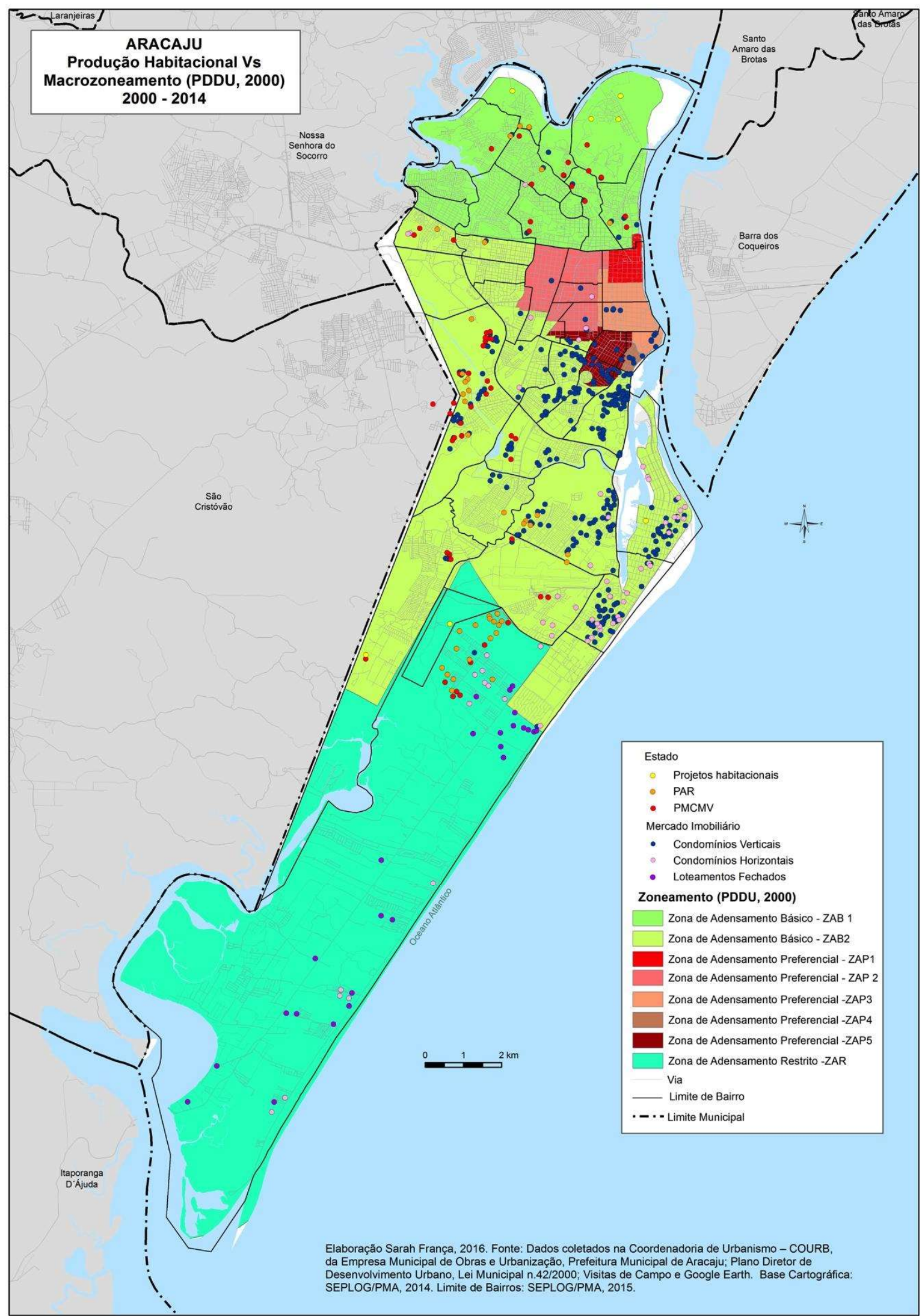

Figura 4: Aracaju, Produção Habitacional e Macrozoneamento, 2000-2014.

Fonte: FRANÇA, 2016 
Quanto à dotação de infraestrutura e acessibilidade esses bairros apresentavam deficiência, de acordo com o Plano Diretor. Porém, atualmente, a oferta de saneamento básico, serviços públicos e equipamentos coletivos na ZAB 2 é crescente, em função das obras de melhorias no esgotamento sanitário e sistema viário, realizadas nos últimos anos, acarretando um aumento do valor da terra. Diante disso, o interesse do mercado aumentou, trazendo para esses locais novos empreendimentos fechados, favorecidos também pela proximidade de espaços coletivos, como o Calçadão da 13 de Julho e o Shopping Jardins.

No caso da Zona de Adensamento Preferencial - ZAP, conforme suas diretrizes de incentivo à ocupação, dada a oferta de infraestrutura, equipamentos urbanos e boa acessibilidade, deveria receber mais empreendimentos, proporcionando um adensamento maior através do coeficiente de aproveitamento máximo variando entre 4,00 e 6,00. Entretanto, o estímulo à instalação de uso residencial, nas áreas comerciais e de serviços, pelo mercado tem sido mínimo, em decorrência da exiguidade de vazios urbanos e com dimensões que não permitem a implantação de empreendimentos imobiliários. Sendo assim, dos 50 condomínios que foram construídos, 45 são de tipologia vertical, e o restante, são condomínios horizontais de pequeno porte, exceto o Cond. Vivendas de Aracaju, no bairro Siqueira Campos, com 485 unidades (Tabela 4 e Figura 4). Os demais, localizados nos bairros Suíça e Cirurgia, dispõem de 6 a 16 unidades habitacionais.

$\mathrm{Na}$ Zona de Adensamento Restrito - ZAR (equivalente à grande parte da Zona de Expansão Urbana), cujo conceito refere-se ao déficit de infraestrutura e presença de restrições ambientais, foram licenciados 67 empreendimentos (12\% do total), quantidade superior àquela da ZAB 1 e ZAP (Tabela 4 e Figura 4). O interesse do mercado aumentou progressivamente em função do baixo valor da terra, comparado às demais similares, pela paisagem ambiental e proximidade aos elementos naturais e às áreas mais valorizadas da zona leste e sul, como 13 de Julho, Jardins e Atalaia.

Todavia, o grande entrave da ZAR é o antagonismo entre legislação (diretrizes de estruturação urbana) e realidade, em função dos índices urbanísticos elevados, que beneficiam os agentes produtores da moradia, desconsiderando a capacidade do saneamento básico (esgotamento sanitário e especialmente drenagem). A permissividade das normas para parcelamento do solo é significativa tendo em vista o coeficiente de aproveitamento máximo até 3,5, a taxa de permeabilidade equivalente a 5\% e a de ocupação com 90\% (FRANÇA, 2011).

Assim, a legislação torna-se um fator decisivo pois os instrumentos de controle urbano permitem que a ocupação agrave cada vez mais o panorama ambiental, ao possibilitar ao mercado imobiliário a 
apropriação de maior espaço. Esses atuais índices, tidos como controladores, não inibem quaisquer adensamentos. (ibidem, p.171).

Quanto à estruturação urbana, verifica-se que a definição do coeficiente de aproveitamento elevado patrocinou os interesses dos incorporadores imobiliários, sobretudo favorecendo a ZAP 4 e 5 , ZAB 2 e ZAR, que corresponde a bairros valorizados e com poucos vazios urbanos, mais centralizados, portanto sendo, ao longo desses anos, adensados. Ao comparar os vetores de expansão até 1999, com os atuais, comprova-se que o Macrozoneamento estabelecido pelo Plano Diretor, aprovado em 2000, deu continuidade à tendência do crescimento em direção oeste e sul, adotada até então. Os bairros na porção oeste da ZAB 2, como o Jabotiana e a Zona de Expansão Urbana, na ZAR, ambos com infraestrutura quase ausente e sistema viário fragmentado, mas com índices urbanísticos elevados, foram alvo do mercado imobiliário e do Estado, no tocante à produção de empreendimentos habitacionais. Diante disso, FRANÇA (2011, p.171) reflete que

faz-se necessário estabelecer critérios, além de fortalecer diretrizes e instrumentos da legislação. O mais grave é a negligência, ao definir o mesmo coeficiente para toda a cidade, uma vez que as zonas têm características diferentes e peculiares, principalmente quando se refere à ZEU, que dispõe de infraestrutura precária e condições ambientais muito frágeis, mas com forte tendência ao adensamento.

O Plano Diretor ainda determina Áreas Especiais, com diretrizes específicas, sendo perceptível a pressão do mercado ao redor das Áreas de Desenvolvimento Econômico ${ }^{4}$ - ADEN's, em especial nos bairros Inácio Barbosa e Grageru, com concentração de edificações verticais na quadra posterior às margens da Avenida Heráclito Rollemberg, onde estão os galpões de grandes lojas e pequenas fábricas remanescentes do Distrito Industrial, que persistem na malha urbana.

Quanto às Áreas de Interesse Ambiental ${ }^{5}$, especialmente na ZEU, a ocupação se sobrepõe, como as lagoas de drenagem, localizadas ao norte da zona, consideradas áreas que devem ser mantidas por se constituir canais de drenagem natural, entretanto, os empreendimentos do PAR e do PMCMV, bem como a construção do bairro 17 de Março, incidiram sobre algumas delas, causando conflitos, em decorrência de alagamentos. Outra sobreposição ocorreu nos parques ecológicos que protegem as dunas, ao longo da Rodovia Inácio Barbosa, nas proximidades do Loteamento Aruana, e ao sul (FRANÇA, 2011).

\footnotetext{
${ }^{4} \mathrm{O}$ foco nas ADENs é a consolidação de um eixo de atividade de desenvolvimento tecnológico e empresarial, não permitindo o uso residencial

5 Embora essas demarcações de áreas ambientais estejam desatualizadas perante a existência ou desaparecimento de algumas, atualizações de estudos técnicos e do Diagnóstico Urbano e Ambiental elaborados em 2005, em 2011 e recentemente, em 2015, observaram as alterações nesses aspectos.
} 
Outro ponto de conflito corresponde aos conjuntos habitacionais nos bairros Porto D'Antas e Lamarão, próximos às áreas de interesse ambiental, como mangue e faixa circundante (ARACAJU, 2000). Chagas (2009) assegura que, para implantação do primeiro conjunto, financiado pelo Programa de Aceleração do Crescimento - PAC e localizado próximo à Área de Preservação Estadual Morro do Urubu, foram aterradas duas lagoas, que, de acordo com funcionário da SEPLAN, são resultados do acúmulo de água que naturalmente escorreriam para o rio, mas tiveram seu percurso interrompido pelas edificações na encosta do morro, o que não justifica a sua preservação. Tal opinião se contrapõe a proposta do Plano de Manejo da APA para a área, que considera necessária a recuperação ambiental desses ecossistemas lacunares, que já sofriam processo de eutrofização e sedimentação (lagoa oeste) e aterramento (lagoa leste) (p.84).

Entrave semelhante, mas tendo como alvo o mangue, ocorreu no bairro Jabotiana, na porção oeste, próximo ao limite com o município de São Cristóvão, onde empreendimentos dos Programas de Arrendamento Residencial e o Minha Casa Minha Vida, e condomínios verticais avançam sobre essas áreas ambientais, privilegiando a produção habitacional em detrimento às normas de preservação.

Outras fortes pressões foram provocadas pelo mercado imobiliário para ocupar o entorno de áreas que deveriam ser resguardadas e aconteceram no bairro Jardins, no entorno do Parque Ecológico Tramandaí, especialmente na parte norte, nas imediações do Loteamento Garcia, nos últimos cinco anos. Além disso, também ocorreram no entorno do Parque da Sementeira, e no bairro Farolândia, no Parque Ecológico, às margens do rio Poxim. Diante desses conflitos, é preciso avaliar

até quando será aceito o aterramento das lagoas e a demolição das dunas, riquezas tão peculiares e importantes. Existe uma Lei de Crimes Ambientais, entretanto para seu devido cumprimento, falta fiscalização dos órgãos competentes. Assim, o que se ressalta é que o Estado, muitas vezes, provoca mais tensões do que as controla (FRANÇA, 2011, p.16).

A discussão referente à pressão pela ocupação dessas áreas ambientais aponta os efeitos negativos da ocupação do solo não planejada. Os habitantes enfrentam dificuldades, sem contar com o apoio do Poder Público no que concerne ao controle e fiscalização da execução das normas que tem se mostrado cada vez mais incipiente (FRANÇA, 2011).

Ainda que a legislação tenha determinado diretrizes de adensamento por zonas ${ }^{6}$, em muitas áreas em que foram previstas especificidades, estas são insuficientes e ineficientes. Todavia, a normativa não incorporou as reais condições de cada zona, a fim de diminuir conflitos entre ocupação e manutenção das características ambientais, acentuando a incidência de alagamentos e inundações,

\footnotetext{
${ }^{6}$ Os índices urbanísticos ditos de controle da ocupação, como taxa de ocupação, taxa de permeabilidade e coeficiente de aproveitamento são semelhantes nas diferentes zonas, não restringindo ou diferenciando o adensamento entre estas.
} 
como aconteceu nos últimos anos principalmente no bairro Jabotiana e na ZEU. Neste caso, o Plano Diretor

contempla a problemática urbana e ambiental e preconiza o adensamento restrito na ZEU, enfatizando a priorização de verbas orçamentárias no resgate do déficit de infraestrutura, equipamentos urbanos e serviços comunitários. [...] Na prática, vem ocorrendo um descompasso entre ocupação e uso do solo e dotação de recursos para infraestrutura, havendo um distanciamento da verdadeira restrição ao adensamento, considerando a capacidade de saneamento ambiental, especialmente esgotamento sanitário e drenagem urbana (FRANÇA, 2011, p.171).

O entrelaçamento da produção habitacional e das intervenções realizadas pelo Estado é notório, sobretudo nas áreas já adensadas, onde houve a construção de pontes, que viabilizaram a aproximação entre dois bairros, preenchendo vazios, como no caso da ponte Gilberto Vilanova, sobre o Rio Poxim, interligando os bairros Farolândia e Inácio Barbosa. Essa intervenção teve como resultado a transformação do uso residencial em comércio e serviços ao longo da Avenida Paulo VI, e nessa proximidade, implantados novos condomínios verticais.

Outras intervenções pontuais, como a Revitalização do Farol Estuarino na Farolândia, Reforma da Orlinha do bairro Industrial favoreceram a chegada de novos empreendimentos habitacionais nas suas proximidades, dinamizando o entorno com outros usos, como comércios e serviços, e além disso, acrescendo valor à terra.

Alguns bairros foram isentos de intervenções urbanas, mas tiveram um fortalecimento na produção habitacional, sob atuação do mercado, remodelando o espaço através do adensamento de vazios urbanos como o Jardins, Grageru e Luzia. No caso dos bairros Coroa do Meio e Atalaia que concentram condomínios verticais e horizontais, apesar de terem sido realizadas diversas obras na Orla de Atalaia durante os últimos anos, essas se constituíram em reformas nas edificações ou acréscimo de algumas, como as quadras de tênis, delegacia, pista de kart, parque infantil, estacionamento, entre outros, não sendo consideradas como elementos de remodelação para o bairro. De fato, o que se identificou foi a força da legislação que abriu frentes para a ocupação, em função da desativação do Farol Estuarino da Farolândia para a Coroa do Meio.

Por fim, é relevante frisar que as avenidas Santa Gleide (em obras) e a Perimetral (em projeto) apontarão novas tendências de ocupação nos bairros limítrofes a Aracaju e Nossa Senhora do Socorro, bem como São Cristóvão nas imediações do bairro Jabotiana, fortalecendo o fenômeno de metropolização iniciado nas décadas de 1970 e 1980, conforme assinalou França (1999). 


\section{VETORES DE ADENSAMENTO E EXPANSÃO URBANA DE ARACAJU: PARA ONDE ESTÁ CRESCENDO A CIDADE?}

Para comprovar o direcionamento da expansão urbana foram selecionados os dez bairros que mais receberam empreendimentos e unidades habitacionais, o que permitiu examinar que alguns apontados apresentam aspectos como grande quantidade de vazios que se caracterizam como estoque de terra, a exemplo da ZEU, Jabotiana e Porto D’Antas. Outra questão foi a permissividade da legislação que incentivou o adensamento de bairros como Jardins, 13 de Julho, Luzia, Farolândia na Zona de Adensamento Básico. A apuração desses dados gerou uma classificação dos bairros de maior investimento do mercado imobiliário, demonstrando a direção e caracterização dos vetores de adensamento e de expansão urbana, em termos quantitativos (Tabela 5).

Nesse âmbito, a Zona de Expansão se destaca não só como a que mais recebeu empreendimentos, mas com a segunda posição em quantidade de unidades habitacionais licenciadas, com 8.292, perdendo apenas nesse quesito para o bairro Jabotiana, em franco crescimento. Nesses dois, a valorização fundiária tem crescido substancialmente, acompanhada pelas intervenções públicas e particulares que substituem terrenos por empreendimentos multifamiliares. O bairro Farolândia assume a terceira posição em ambas as classificações, bem como Coroa do Meio, Atalaia e Luzia (Tabela 5).

\section{Tabela 5 \\ Aracaju}

Classificação dos Bairros por empreendimentos e unidades habitacionais

2000 - 2014

\begin{tabular}{|c|c|c|c|c|c|}
\hline \multicolumn{3}{|c|}{ Empreendimentos } & \multicolumn{3}{c|}{ Unidades Habitacionais } \\
\hline Classificação & Bairro & Quantidade & Classificação & Bairro & Quantidade \\
\hline $1^{\circ}$ & Zona de Expansão & 69 & $1^{\circ}$ & Jabotiana & 9.953 \\
\hline $2^{\circ}$ & Jardins & 64 & $2^{\circ}$ & Zona de Expansão & 8.292 \\
\hline $3^{\circ}$ & Farolândia & 58 & $3^{\circ}$ & Farolândia & 8.061 \\
\hline $4^{\circ}$ & Atalaia & 56 & $4^{\circ}$ & Luzia & 4.512 \\
\hline $5^{\circ}$ & Jabotiana & 51 & $5^{\circ}$ & Jardins & 3.379 \\
\hline $6^{\circ}$ & Coroa do Meio & 42 & $6^{\circ}$ & Santa Maria & 3.357 \\
\hline $7^{\circ}$ & Luzia & 29 & $7^{\circ}$ & Porto D'Antas & 2.725 \\
\hline $8^{\circ}$ & Grageru & 27 & $8^{\circ}$ & 17 de Março & 2.562 \\
\hline
\end{tabular}




\begin{tabular}{|r|r|c|c|c|c|}
\hline $9^{\circ}$ & Inácio Barbosa & 15 & $9^{\circ}$ & Atalaia & 2.318 \\
\hline $10^{\circ}$ & 13 de Julho & 13 & $10^{\circ}$ & Coroa do Meio & 2.069 \\
\hline & Total & 424 & & Total & 47.288 \\
\hline & Total Aracaju & 519 & Total Aracaju & 62.587 \\
\hline & $\%$ & 81,69 & $\%$ & 75,55 \\
\hline
\end{tabular}

Elaboração Sarah França, 2016.

Fonte: Dados coletados em pesquisa de campo e na Coordenadoria de Urbanismo da Empresa Municipal de Obras e Urbanização - EMURB/PMA, 2015.

Entre os anos 2000 e 2014 foi constatada a formação de novos vetores de expansão urbana e o fortalecimento de alguns existentes até 2000, em direção aos principais eixos viários. No caso dos vetores que se formam ao norte, partindo do bairro Industrial, no sentido dos bairros Porto D'Antas, Lamarão e Bugio é relevante recordar a proximidade com o limite de Nossa Senhora do Socorro, além da presença de fortes ligações viárias entre a capital e este município, situadas, nos arredores dos principais conjuntos habitacionais construídos pelo Estado (Figura 5). 


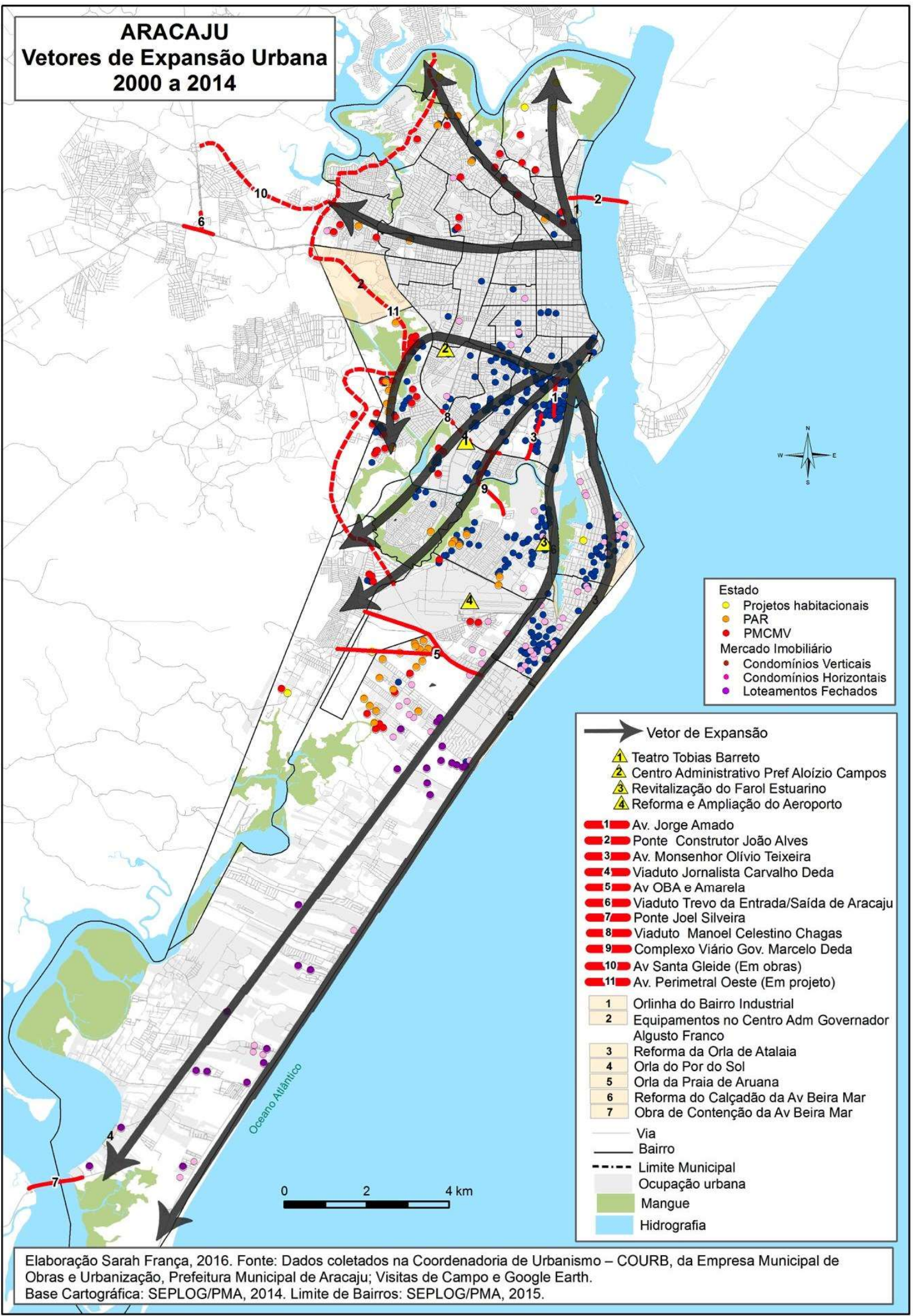

Figura 5: Aracaju, Vetores de Expansão Urbana, 2000-2014.

Fonte: FRANÇA, 2016 
Ao norte estão os bairros destacados pelo desinteresse do setor imobiliário por abrigarem moradias de grupos de renda mais baixa, com assentamentos precários e irregulares. Assim, desde a primeira metade do século XX, a provisão de moradia para esse grupo econômico pelo Estado se deu fora do tecido consolidado, em bairros como Porto D’Antas, Lamarão, Olaria, Soledade, justificados pelo valor fundiário reduzido, produzindo habitações com custo reduzido, embora com maior ônus no que diz respeito à implantação de infraestrutura e custos de vida desses moradores. Nesta área, notou-se uma redução dos investimentos públicos em infraestrutura, mas com atuação governamental referente à implantação de projetos habitacionais da Prefeitura Municipal e Governo do Estado, além dos empreendimentos subsidiados pelo Programa de Arrendamento Residencial e o Minha Casa Minha Vida, nos últimos 14 anos.

Contraditoriamente, outro ponto de destaque foi a intensificação da produção habitacional em bairros já verticalizados, como 13 de Julho, Jardins, Grageru. Estes foram consolidados como local de moradia de famílias de maiores rendimentos, com condomínios de 1 ou 2 blocos, cuja apropriação se constitui um relevante mecanismo de apropriação do capital, adensando os escassos vazios existentes e valorizando, por conta disso, os imóveis a venda, sobretudo no entorno do shopping Jardins, nos novos loteamentos Garcia e Jardim Europa. Atrelado à isso, a chegada de empreendimentos econômicos como boutiques de capital local, lojas de franquias nacionais, escolas, hospital, centro médico, supermercado, restaurantes auxiliou na formação de uma nova centralidade, direcionada à clientela de luxo, homogeneizando social e economicamente esses espaços.

Nessa proximidade, o bairro Luzia, caracterizado antes, pela presença de conjuntos habitacionais subsidiados pelo Banco Nacional de Habitação, hoje aponta a duas novas áreas de atuação do mercado imobiliário, com a inserção de condomínios verticais. A primeira corresponde à Alameda das Árvores, uma avenida construída sob responsabilidade de apenas uma construtora, com seus prédios verticais às suas margens, enquanto a segunda, nas proximidades da avenida Adélia Franco, foi ocupada com vários empreendimentos verticais de grande porte (até 12 blocos de 16 pavimentos cada), o que faz este bairro despontar no quesito quantidade de unidades habitacionais.

Dois outros bairros foram alvo da intervenção da iniciativa privada associada à atuação do Estado. O primeiro, o Inácio Barbosa, que recebeu equipamentos públicos e privados, atrelados à construção do Complexo Viário Marcelo Déda, composto por três intervenções viárias, de interligação entre bairros. Posteriormente, alterações não só nas tipologias habitacionais predominantes (residências unifamiliares para multifamiliares), mas também para uso comercial e de serviços, permitindo a chegada de novos agentes e usuários do espaço produzido. Nesse caso, fica visível observar que o "anúncio" prévio de uma intervenção urbanística serviu como elemento atrativo para a 
apropriação do espaço pelo mercado imobiliário, na tentativa de formação de um novo espaço para verticalização, e assim, captação de maior lucro.

Já o bairro Farolândia, desponta em função da presença de novos condomínios verticais atraídos cuja atratividade da Universidade Tiradentes, como polo gerador de demanda por moradia para classe de renda média, somada à Revitalização da praça do Antigo Farol, fortaleceram a área para apropriação do mercado imobiliário. Em outras imediações do bairro, diferentes tipologias habitacionais são inseridas como, contraditoriamente pode-se destacar o condomínio horizontal mais luxuoso de Aracaju, nas imediações do Parque dos Cajueiros, ou empreendimentos do PAR e do PMCMV na porção mais oeste, na franja do conjunto Augusto Franco.

Novos vetores de expansão também foram apontados em áreas pouco exploradas pela incorporação até 2000, fora do eixo Jardins/13 de Julho/Grageru, como os bairros Atalaia, Coroa do Meio (vetor sul) e Luzia (vetor sudoeste). Esses dois primeiros foram isentos de ocupação vertical, em detrimento do controle da legislação federal, referente ao cone do Farol Marítimo, até o final da década de 1990. Posteriormente, a paisagem do bairro Atalaia se transformou, de predominantemente horizontal, para traços verticais especialmente na porção mais sul, cuja terra é mais valorizada, aproveitando fatores como proximidade da praia e facilidade de acesso ao Centro.

No caso das áreas antes inexploradas pela incorporação imobiliária predomina a orientação ao oeste para o bairro Jabotiana, próximo aos limites entre Aracaju e São Cristóvão. A produção habitacional nesse bairro se caracteriza de forma fragmentada e segregada, através de empreendimentos dos Programas de Arrendamento Residencial e Minha Casa Minha Vida, em sua maioria, condomínios verticais construídos pelo capital e Estado, ocorrendo intercaladamente ou mesmo avançando sobre áreas de preservação ambiental, como mangues e lagoas. Entretanto, as intervenções viárias realizadas de ligação dessa área com os outros bairros proporcionaram cada vez mais acelerado a ocupação desses espaços, sem infraestrutura e com condições ambientais frágeis, acirrando problemas como ocorrência de enchentes no período de chuvas.

Dando continuidade aos vetores indicados ao oeste, a partir dos bairros Jardins e Grageru, observa-se a ocupação no bairro Jabotiana no extremo, e do São Conrado até o Santa Maria (fortalecendo este como vetor de expansão sudoeste). Nesses nota-se presença de empreendimentos habitacionais do PAR e PMCMV, construídos sob a responsabilidade do Estado, mas também, apontando a atuação do mercado imobiliário com implantação de condomínios verticais.

O bairro Jabotiana, assim como a ZEU, um dos maiores vetores de expansão urbana de Aracaju, se fortaleceu a partir de 2002, com a implantação de conjuntos verticais do Programa de Arrendamento Residencial. Nos anos seguintes, a implantação do cemitério-parque Colina da Saudade, trouxe a circulação de um novo público e contribuiu para possibilitar a atração de novos investimentos privados 
e públicos, além da modificação dos usos nas principais avenidas, apontando a formação de uma nova centralidade de comércio e serviços locais. A partir de 2009, o PMCMV, em especial com empreendimentos fechados destinados à faixa de 3 a 10 salários mínimos é responsável por intensificar o preenchimento dos vazios de forma fragmentada, apesar de oferecer condições incipientes de saneamento básico, especialmente drenagem urbana, somados à infraestrutura viária, sem planejamento para suportar o atendimento dessas novas famílias ali residentes.

De forma semelhante, ao sul, o fortalecimento dos vetores traçados, nas duas últimas décadas do século XX, despontou na ZEU como uma forte tendência para apropriação do capital, com inúmeros loteamentos fechados e condomínios horizontais para veraneio, localizados ao longo das Rodovias dos Náufragos e Inácio Barbosa. Isso está associado às intervenções viárias executadas pela Prefeitura e pelo Governo Estadual, com o propósito de facilitar o acesso não só daqueles que ali residem, mas aos que usufruem das praias. Assim, a segregação e fragmentação do espaço ganharam maior força a partir de 2000, especialmente na porção norte, com a implantação dos conjuntos habitacionais do PAR e do PMCMV, baseadas na permissividade das normas do Plano Diretor, e nas intervenções urbanísticas realizadas pelo Estado, como abertura de vias (OBA e Amarela), a construção das orlas de Aruana e Mosqueiro valorizaram a área.

O alto valor da terra em áreas urbanizadas é considerado um fator de dificuldade para escolha por ocupar bairros centrais, a depender do produto imobiliário a ser trabalhado. Essa questão auxilia na compreensão da escolha da localidade para construção de empreendimentos que demandam mais área, como os conjuntos habitacionais construídos pelo Estado, direcionados para uma classe popular, fato este que possibilitou nesta localidade, a construção do complexo habitacional pela Prefeitura Municipal (cerca de 2500 moradias), hoje denominado bairro 17 de Março.

Por outro lado, também foram inseridos condomínios horizontais e loteamentos fechados, atendendo famílias de renda mais elevada que buscam segunda residência para veraneio e finais de semana, caracterizados pela segregação e homogeneização social. De fato, a implantação desses produtos, demanda localização privilegiada com a presença de amenidades naturais, o que somado à ausência de glebas, reduz a sua oferta em áreas mais centrais, distanciando-os para fora da malha urbana consolidada. A fragmentação e dispersão do espaço, face à deficiência de infraestrutura e serviços públicos, acirrando sérios entraves ambientais, como também ocorre no bairro Jabotiana, deve ser objeto de urgente análise nos processos de planejamento urbano na gestão municipal.

Contudo, ficou evidenciada a continuidade da apropriação de áreas pelo mercado imobiliário e pelo Estado, fortalecida pelas intervenções urbanísticas, e que ainda têm direcionado a expansão não só para as margens do tecido consolidado, como para fora dos limites municipais. Por outro lado, fica claro que surgem novas áreas em expansão, em direção à espaços sem oferta de saneamento básico, 
fragmentando o tecido urbano e acirrando conflitos socioambientais, para abrir frentes de atuação do capital privado.

\section{REFLEXÕES FINAIS}

Ao estudar a interferência do Plano Diretor na produção da cidade de Aracaju, aponta-se que, nos últimos anos, a lógica da reprodução do mercado imobiliário foi apoiada pelo Estado, em que diversos espaços são identificados como reduto da implantação de empreendimentos residenciais, produzindo novas áreas ou adensamento de espaços vazios existentes em bairros urbanizados.

O grande entrave se concentrou na deficiente atuação do Estado para implementação dos instrumentos urbanísticos de regulação da terra e controle da especulação imobiliária. Além disso, verificou-se uma deficiência no provimento de habitação direcionada, realmente, para interesse social, que contribuiria na conquista pela efetivação do direito à moradia para grupos de renda mais baixa. $\mathrm{A}$ ausência de alternativas concretas de acesso à habitação contribuiu para o incremento do valor dos imóveis e, consequentemente, na segregação, exclusão e expulsão de grande parcela da população das cidades.

Assim, fez-se importante refletir sobre como a legislação interfere na construção sócioespacial e na negação da implementação do direito à cidade para atender interesses da sociedade capitalista, que contrariam necessidades da maioria da população. Cidades como Aracaju refletem injustiças sociais, diferenças econômicas e conflitos de classe em detrimento da conquista por maior renda fundiária e lucro imobiliário, o foco dos agentes produtores do espaço urbano.

A partir do exposto, ficou evidente que esses dois agentes se envolveram na produção do espaço capitalista de Aracaju, e se sobrepuseram a favor consolidação dos vetores de adensamento e expansão urbana. Desse jogo de interesses dos diversos agentes resultou um novo tipo de urbanização, marcada, a partir de 2000, sobretudo pela extensão e descontinuidade do tecido urbano, proporcionando caráter complexo às novas formas segregadas, extrapolando limites administrativos, principalmente no que diz respeito aos hábitos de consumo e às práticas socioespaciais da população.

A combinação entre multiplicidade de agentes e diferenciação de renda e de ciclo dos compradores tornou o mercado particularmente segmentado, social e espacialmente. De um modo geral, as pesquisas convergiram na certificação de que a produção habitacional formal foi predominante assumida pelos incorporadores imobiliários (construtoras, proprietários fundiários, corretoras), proporcionada para as classes média-alta e alta. Esse mercado é restrito, especulativo e excludente, sendo, na maioria das vezes, sob a forma de incorporação residencial através de condomínios fechados.

Por esse motivo, a urbanização dispersa permitida, através de uma legislação fragmentada que não reflete as reais potencialidades da cidade, trouxe sérios transtornos à população. Verifica-se a 
necessidade de um Plano Diretor efetivo, com diretrizes efetivas para um zoneamento diferenciado, elaborado em função do potencial construtivo, infraestrutura e sistema viário. A fragmentação das normas propiciou a explosão de empreendimentos fechados para os vetores norte, oeste e extremo sul, que correspondem às áreas carentes de infraestrutura. Outro resultado foi o acirramento das problemáticas apresentadas em áreas adensadas e verticalizadas, à leste e sul de Aracaju. A realização de obras de infraestrutura, sistema viário e serviços públicos deveria ser planejada concomitantemente a esses projetos habitacionais, para que esses moradores estivessem integrados à cidade.

\section{REFERÊNCIAS}

ARACAJU. Lei $n^{\circ} 42$ de 06 de outubro de 2000. Institui o Plano Diretor de Desenvolvimento Urbano de Aracaju e dá outras providências. Aracaju, SE. 06 de outubro de 2000.

ARAÚJO, Rozana Rivas de. As relações entre as transformações econômicas e o ritmo da produção do espaço urbano. Estudo de caso: Aracaju. Tese (Doutorado em Planejamento Urbano e Regional) Universidade Federal do Rio Grande do Sul, Porto Alegre: 2011.

FRANÇA, Sarah Lúcia Alves França. Estado e Mercado na produção contemporânea de habitação de Aracaju-SE. Tese (Doutorado em Arquitetura e Urbanismo) - Universidade Federal Fluminense, Niterói: 2016.

FRANÇA, Sarah Lúcia Alves França. A produção do espaço na Zona de Expansão de Aracaju/SE: dispersão urbana, condomínios fechados e políticas públicas. Dissertação de Mestrado (Doutorado em Arquitetura e Urbanismo) - Universidade Federal Fluminense, Niterói: 2011.

França, Vera Lúcia Alves França. Aracaju: Estado e Metropolização. - São Cristóvão: Editora UFS, 1999.

LEFEBVRE, Henry. O direito à cidade. São Paulo: Centauro, 2001.

SECRETARIA MUNICIPAL DE PLANEJAMENTO, ORÇAMENTO E GESTÃO. (SEPLOG); FRANÇA, Vera Lúcia Alves. Diagnóstico da Cidade de Aracaju. Relatório Final. Etapa 03. Aracaju: PMA/SEPLOG, 2014.

Trabalho enviado em 01 de junho de 2019

Aceito em 02 de fevereiro de 2020 